Primljen / Received: 22.2.2012

Ispravljen / Corrected: 15.8.2012.

Prihvaćen / Accepted: 7.9.2012.

Dostupno online / Available online: 15.10.2012.

\section{Shrinkage strain of concrete - causes and types}

Authors:

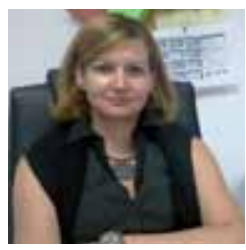

Asst.Prof. Merima Šahinagić-Isović, Ph.D. CE University "Džemal Bijedić" in Mostar Faculty of Civil Engineering merima.sahinagic@unmo.ba

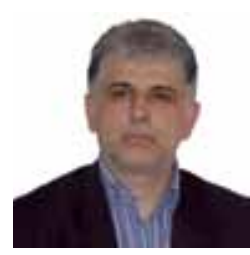

Prof. Goran Markovski, Ph.D. CE

University "Sv. Kiril i Metodije" Skopje

Faculty of Civil Engineering

markovski@gf.ukim.edu.mk

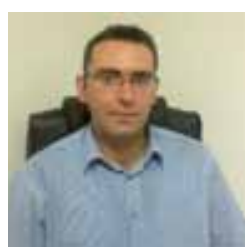

Marko Ćećez, B.Sc. CE

University "Džemal Bijedić" in Mostar

Faculty of Civil Engineering

marko.cecez@unmo.ba

\section{Merima Šahinagić-Isović, Goran Markovski, Marko Ćećez}

Subject review

\section{Shrinkage strain of concrete - causes and types}

The shrinkage represents a time dependent deformation which reduces the volume of concrete, without the impact of external forces. The time flow and the final values of shrinkage are influenced by numerous factors: temperature and humidity, dimensions of elements, the type and quantity of cement, w/c factor, granulometric and mineralogical composition of aggregates, concrete strength, method of workability and curing, concrete age at the end of curing and many other factors. Basically, it is a combination of several basic types of shrinkage which will be presented in this paper.

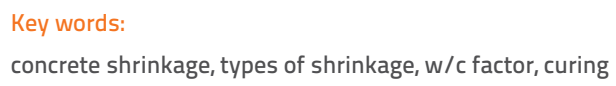

Pregledni rad

\section{Merima Šahinagić-Isović, Goran Markovski, Marko Ćećez}

\section{Deformacije skupljanja betona - uzroci i vrste}

Skupljanje predstavlja vremensku deformaciju smanjenja volumena betona bez djelovanja vanjskih sila. Na vremenski tijek i konačne vrijednosti skupljanja utiče vrlo mnogo čimbenika: temperatura i vlažnost okoline, dimenzije elementa, vrsta i količina cementa, v/c faktor, granulometrijski i mineraloški sastav agregata, čvrstoća betona, način ugradnje i njega betona, starost betona u trenutku prekida njege i dr. Suštinski, ono je kombinacija nekoliko elementarnih vrsta skupljanja koji će biti izneseni u radu.

Ključne riječi:

skupljanje betona, vrste skupljanja, v/c faktor, njega betona

Übersichtsarbeit

\section{Merima Šahinagić-Isović, Goran Markovski, Marko Ćećez}

\section{Deformierungen der Betonzusammenziehung - Ursachen und Arten}

Kontraktion stellt eine durch Zeit bedingte Deformation der Verminderung des Betonvolumens ohne Einwirkung von Außenkräften dar. Auf den zeitlichen Verlauf und die Endwerte üben viele Faktoren Einfluss: Temperatur und Feuchtigkeit der Umgebung, Elementdimensionen, Art und Menge des Zements, W/Z -Faktor, die Zusammensetzung von Korngröße und Mineralogie des Aggregats, Betonfestigkeit, Art des Einbaus und Betonpflege, Betonalter zum Zeitpunkt der Pflegebeendigung u. A. Im Grunde handelt es sich um eine Kombination von mehreren elementaren Kontraktionsarten, die in der Arbeit bearbeitet werden. 


\section{Introduction}

During the hardening process of concrete due to the effects of cement hydration and concrete drying process due to water loss, there is a reduction of the concrete volume. Concrete shrinkage is a characteristic where the concrete changes its volume over time in a way that it decreases dimensions of unloaded concrete constructions proportionally in all directions. As porous hard material, concrete starts deforming as soon as it is exposed to mechanical, thermal or hydrologic effects. Therefore, when it comes to origin of concrete shrinkage we can talk about its three aspects: chemical thermal and hydrologic processes [1].

Hydrological effects, as well as thermal effects, are the result of environmental conditions changes or changes in the concrete mass. Under the environmental conditions change we consider the changes of temperature and humidity. Under the changes within the concrete mass we are considering: heat produced by cement hydration and self-desiccation [2, 3], which is result of hydration continuation after concrete binding, ie reduction in relative humidity due to the hydration process [2]. As a consequence, all these changes suffer from decrease in temperature and hydraulic potential of construction i.e. they cause a loss of equilibrium conditions with environment. Therefore, strains that occur are never uniform. They cause constructive effects and stresses.

\section{Required material properties for defining shrinkage}

In order to understand, analyze and quantify all these effects on concrete shrinkage we need information regarding the following four elements:

- mechanical effect of temperature changes;

- thermal effect of cement hydration;

- hydrological effect when it comes to hydration;

- hydrological effect when it comes to climate [1].

To define mechanical effect of temperature changes we need to determine the value of temperature change over time as well as the change of - concrete elasticity module and coefficient of thermal expansion (CTE). For mentioned parameters, we need to determine laws of their change over time.

Concrete elasticity module is deformation of concrete under short-term load. Elasticity module develops significantly during the hardening, as well as mechanical strength, same as the compressive strength, we can consider module as monotonous continual increasing function of concrete age. Choice of aggregate has the biggest effect on elasticity module. Primarily, due to a larger share of aggregate (70 - 80 $\%$ ) in the whole composite mass compared to cement paste share, secondly because, in general, there is less room to change parameters that are changing module with aggregates than that are changing with cement mass. This second reason is closely connected to the aggregate effect on mechanical composite strength.

Similar to elasticity module, coefficient of thermal expansion (CTE) depends more on aggregate than on cement paste due to volume relations. Coefficient of thermal expansion of cement paste varies from $11 \times 10^{-6}$ to $20 \times 10^{-6} 1 /{ }^{\circ} \mathrm{C}$, which depends of humidity, while coefficient of thermal expansion of aggregates varies from $1 \times 10^{-6}$ to $14 \times 10^{-6} 1 /^{\circ} \mathrm{C}$, which depends of type of rock. Coefficient of thermal expansion values for concrete varies from 6 or $7 \times 10^{-6} 1 /^{\circ} \mathrm{C}$ for concrete with lime aggregate to 12 or $13 \times 10^{-6} 1 /^{\circ} \mathrm{C}$ for concretes with silica aggregate. With sufficient accuracy in practice, we mostly adopt value of coefficient of thermal expansion for concrete from $10 \times 10^{-6} 1{ }^{\circ} \mathrm{C}$. In the other hand, opposite to E-module, coefficient of thermal expansion is practically constant after the first few hours of binding. Coefficient of thermal expansion has important part in elements which are exposed to prevented strains conditions, in cases of massive constructions (for example, dams) or in cases of elements exposed to great changes of temperature (for example, pavements).

To describe the thermal effects of cement hydration is necessary to determine the above mentioned parameters and the law that describes the development of heat during hydration. The hydration heat of cement is the amount of heat per gram of non-hydrated cement, which is released during the hydration process. It depends on chemical composition of cement (it grows with the amount of $C_{3} A$ ) and grinding fineness. Hydration cement heat is an important feature in massive constructive elements (for example, dams, foundation blocks) but also when the elements are exposed to prevented ultimate strains conditions (for example, pavements, concrete plates, composite structures), i.e. in medium thick constructions (smaller than $20 \mathrm{~cm}$ ), when the one side is thermally isolated. With these two construction types, influence of thermal shrinkage is in superimposes with its autogenous shrinkage. Due to hydration, because of heat release, first occurs thermal expansion of concrete, which led to the cooling process of concrete, which represents the thermal shrinkage. Concrete with high hydration heat often have great autogenous shrinkage like in a case of high strength concrete.

For hydrological effects related to hydration we need to establish the law of shrinkage development, which is determined in absence of any kind of hydrologic change with environment. These effects result in autogenous shrinkage which is consistent. If we observe it from a specific scale, the scale where concrete as granular material can be considered as homogeneous, it represents quintuple value from the biggest aggregate grain [1]. Therefore, autogenous shrinkage is internal characteristic of material and it is independent from the specimen size.

For hydrological effects related to climate we need to establish the law of shrinkage development due to environmental 
conditions, which constitute a natural drying. Under environmental conditions implies temperature and humidity. In addition, this law must be an indication of the quantitative element dimensions characteristics of which depends the dynamics of drying. These effects give drying shrinking which depends on the size of the element, and therefore is not internal material characteristics.

\section{Shrinkage types}

According to authors from the region, traditional classification of concrete shrinkage was according to [4]:

- shrinkage due to water evaporation during the cement binding process (plastic shrinkage);

- shrinkage due to contraction of the hydration products (hydration shrinkage);

- shrinkage after cement binding process is complete (hardened concrete shrinkage due to drying or hydraulic shrinkage);

while according to [5] it is:

- autogenous shrinkage;

- plastic shrinkage;

- hardened concrete drying shrinkage;

- carbonation shrinkage.

But shrinking is rather complex phenomenon that depends on numerous factors and represents combination of several elementary forms of shrinkage:

- plastic shrinkage, which develops on the surface of fresh concrete exposed to drying;

- chemical shrinkage, which is consequence of chemical binding i.e. using of water in concrete in the cement hydration process;

- autogenous shrinkage, some called it hydration shrinkage, it is closely connected to chemical shrinkage, and it is a consequence of self-desiccation in pores of cement paste in the process of hydration of non hydrated cement;

- drying shrinkage, when the concrete is exposed to environment what causes evaporation water from capillaries;

- thermal shrinkage, which is result of temperature changes in concrete in the process of hydration;

- carbonation shrinkage, where carbon dioxide from the environment causes chemical reactions in cement stone.

Cause of all this shrinkage types is loss i.e. use of water in concrete, except in the case of carbonation shrinkage, which is a consequence of hydrated cement paste reaction with carbon dioxide from the environment in humidity conditions. Water can either exit from concrete to environment or it can be used in cement hydration. Therefore the size and the grade of concrete shrinkage depend on water cement ratio of concrete mixture, that is, they depend on concrete strength. Total shrinkage should be taken as the sum of each individual volume change due to carbonation, thermal change, drying and autogenous shrinkage [2].

\subsection{Plastic shrinkage}

Plastic shrinkage develops on the surface of the fresh concrete i.e. it is a consequence of water evaporation from the surface of fresh concrete or absorption in the concrete form or bedding. Compared to other types of shrinkage it is the greatest and it size can be $1 \%$ of its cement volume. It is developing very fast in the first several hours and as such mainly it is not registered. Typically, it is not significant compared to stress conditions of constructions because it occurs in the fluid mass of the fresh concrete. It occurs in the cases when due to evaporation of water mixture clots and pieces contained in fresh concrete are moving towards each other. Surface layer shrinkage is prevented in internal parts of concrete which do not shrink what leads to tensile stress in the surface layer. These stresses can be bigger from the tensile strength of young concrete what leads to plastic cracks, shallow and wide. Bigger quantities of cement increase the amount of plastic shrinkage. Damage effects of this type of shrinkage can be eliminated relatively easy by correct and intensive concrete cure i.e. by wetting of concrete elements (or covering with membranes) with the purpose of retrieving water (or to prevent its evaporation).

\subsection{Chemical shrinkage}

Chemical shrinkage of cement paste represents decrease of volume cement paste which occurs due to chemical binding of water in the process of cement hydration.

In the process of concrete hardening, several chemical transformations develop in the cement paste. The direct consequence of these chemical transformations is a decrease of cement paste volume. This phenomenon is clearly shown at the figure 1. Resulting volume of the hydration products, which is formed in the reaction of water and cement is smaller than volume of input components, cement and water together. The main reasons of cement paste volume decrease, if we compare it to volume of water and cement, are increased stiffness of chemically compounded water compared to free water of mixture before binding.

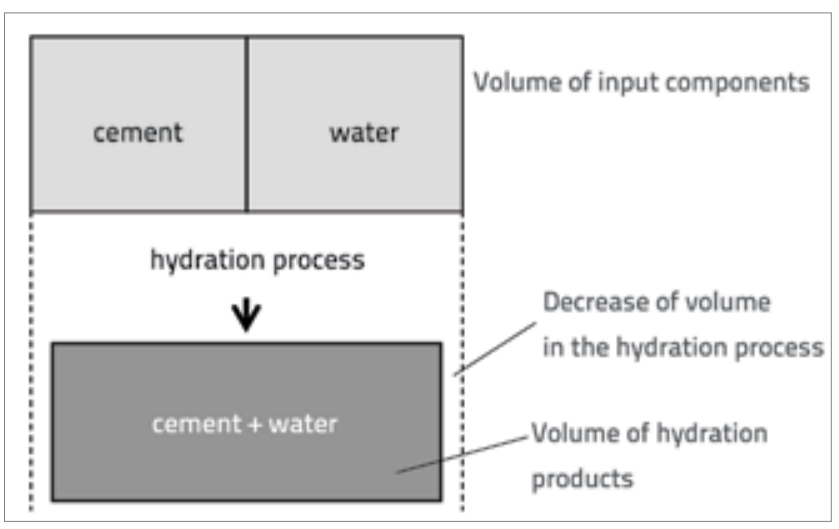

Figure 1. Schematic description of chemical shrinkage mechanism [6] 
Internal forces which occur with development of microstructure by cement paste hardening cause certain strains of cement paste i.e. concrete. At the certain stage of hardening process leads to shrinkage of cement paste causing additional empty pores contributing to increase the joint pore volume in the cement paste that hardens. Pores occurred due to chemical shrinkage have an important position in autogenous shrinkage [6].

\subsection{Autogenous shrinkage}

Autogenous shrinkage of concrete, which some also call hydration shrinkage is a result of self-desiccation process in the pores of cement stone, it is the use of water in the cement hydration processes [7]. Chemical and autogenous shrinkage are very bonded and it is hard to draw the line between these two types of shrinkage. Primarily, chemical shrinkage occurs and then we have additional pores due to hydration. Process of self-desiccation begins in these pores because of the process of hydration i.e. inside the cement stone structure all water is used for hydration and humidity cannot reach fast enough from the outside due to density structure. This leads to shrinkage (even cracks inside the concrete) what we call autogenous shrinkage (Figure 2.). Most of the autogenous shrinkage is done in the first month i.e. in the first days and starts several hours after mixing what depends on the mixture type.

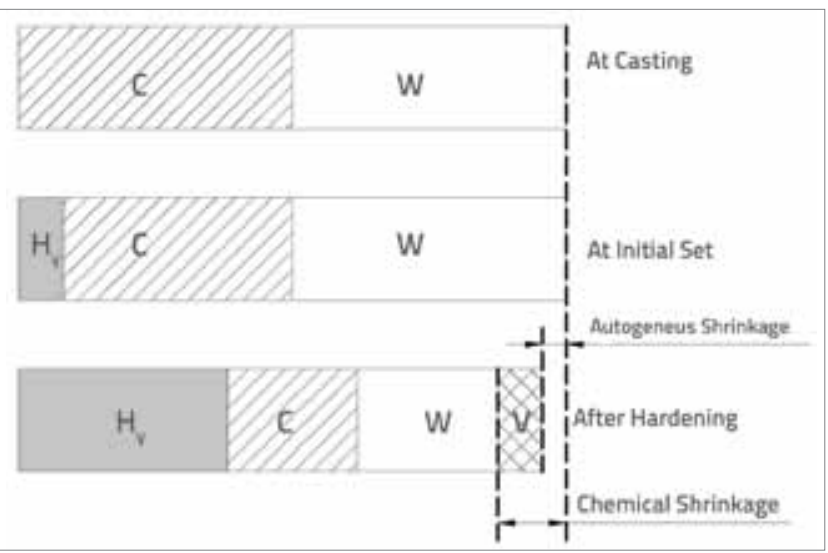

Figure 2. Relations between autogenous and chemical shrinkage: C unhydrated cement, W - unhydrated water, Hy - hydration products, and V - voids generated by hydration [3]

Theoretically, level of autogenous shrinkage development is determined by the degree of cement hydration because most of the autogenous shrinkage occurs in the first month. Time development law of these strains is directly connected to cement hydration dynamic, which on the other side, controls value development of mechanical concrete strength. Parameters that influence this dynamics are therefore the same who influence the increase of the strength value: type and fineness of cement grind and water cement ratio (w/c). Development curve of autogenous shrinkage therefore, is very well compatible with the development of mechanical strength curve. In the first several days, the development of autogenous shrinkage is very fast. It reaches from 60 to $90 \%$ of shrinkage value of 28 days. Total intensity of autogenous shrinkage is moderate, but when we add it to other shrinkages we have non-insignificant values: from 100 to $300 \times 10^{-6}$. Rate of its development in the early stage is of this kind, so this shrinkage was overlooked by the experts for a long time, because conventional shrinkage tests (at least those tests used for determination of the laws mentioned in the calculation rules) begin within 48 hours or 3 days.

Autogenous shrinkage stays less than $10^{-4}$ (figure 3.) for concrete where water cement ratio $(\mathrm{w} / \mathrm{c})$ is greater than 0,45 but increases very fast when this ratio decrease below 0,40 and can reach value of $3 \times 10^{-4}$ (figure 4.) [1].

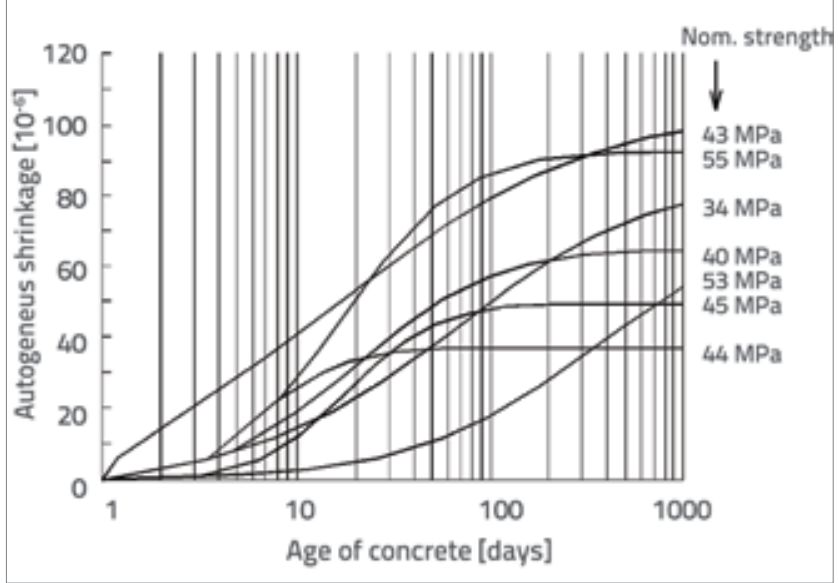

Figure 3. Autogenous shrinkage of the ordinary concretes with different strengths [1]

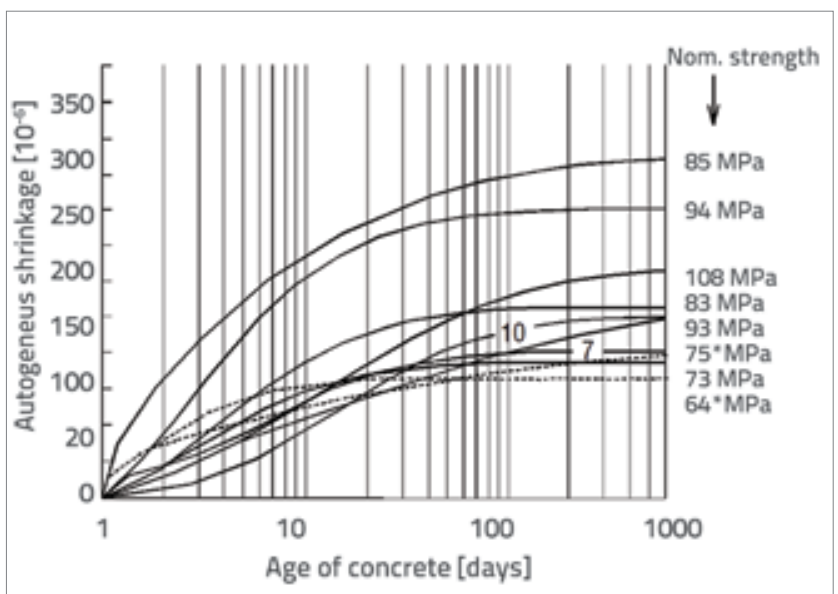

Figure 4. Autogenous shrinkage of the high strength concrete with different strengths ("*_" without silica dust) [1]

Autogenous shrinkage measured with ordinary strength concrete with water cement ratio of 0,54 tested in TNO [8] was practically insignificantly low. This fact is probably the reason why in the past autogenous shrinkage did not have extra 
attention when researching ordinary strength concrete, while with high strength concrete that have very low water cement ratio autogenous shrinkage represents an important part of the total shrinkage process. Generally, autogenous shrinkage increases with the decrease of water cement ratio. Experiments results, which are obtained in France [9], showed that decrease of water cement ratio from 0,41 to 0,33 had caused increase of autogenous shrinkage by $56 \%$. Therefore, autogenous shrinkage with high strength concrete is significantly greater than with ordinary strength concrete. Some researchers have concluded that this is 2 to 2,5 times bigger increase [10]. Autogenous shrinkage of ultra high performance concrete is even more expressive, while the drying shrinkage is very little [11]. And at the self-compacting concrete (SCC), due to the presence of large cement paste volume, autogenous shrinkage is very large [12]. Similarly can be concluded from the results of own experimental tests [6] wherein mixtures of ordinary concrete and high-strength concrete in the form of prisms dimensions $10 / 10 / 40 \mathrm{~cm}$ and age of 420-430 days, were tested. Tested ordinary concrete had water-cement ratio $\mathrm{w} / \mathrm{c}=0,58$, and the mean value of autogenous shrinkage $112 \times 10^{-6}$, while the high strength concrete, had water-cement ratio $\mathrm{w} / \mathrm{c}=0,36$, and the mean value of autogenous shrinkage $264 \times 10^{-6}$ (Figure 5.). As a results showed autogenous shrinkage of high strength concrete is greater than autogenous shrinkage of ordinary concrete by about 2,3 times.

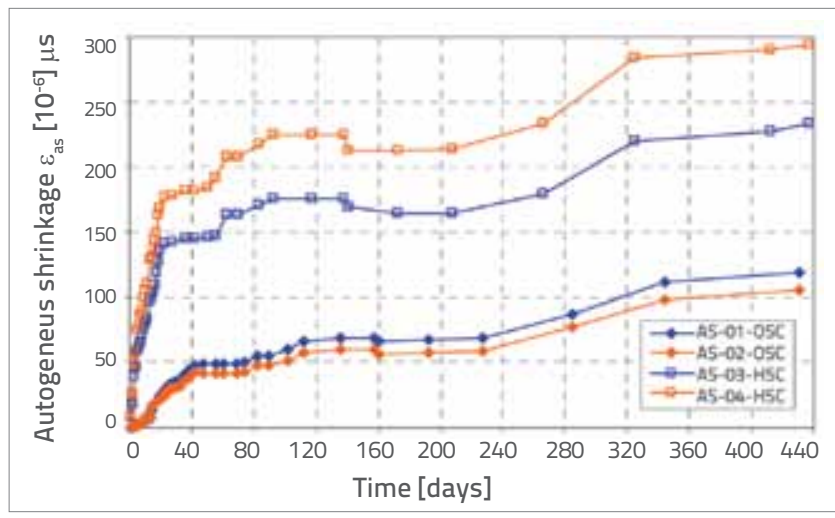

Figure 5. Autogenous shrinkage of ordinary strength concrete (OSC) and high strength concrete (HSC)

Autogenous shrinkage is increased with the increase of micro silica share. This is the result of fine hydrate cement paste micro structure. Having in mind the researches by Le Roy and De Larrard [9], autogenous shrinkage of concrete is increasing by $40 \%$ due to addition of $8 \%$ of micro silica.

\subsection{Drying shrinkage}

Opposite to self-desiccation shrinkage (autogenous shrinkage), this type of shrinkage is reflected from the surface towards the interior of the concrete mass. Drying shrinkage refers to the reduction in concrete volume resulting from a loss of water from the concrete. Initially, free water escapes to the concrete surface as bleed water. Once the bleed water has disappeared, excess water will be pulled from the interior of the concrete mass [2]. Drying level varies according to the thickness of element, between its maximal value (on the surface) and its minimal value (in the core).

Drying shrinkage varies between 2 and $6 \times 10^{-4}$ and it depends on many parameters. Parameters, which influence this type of shrinkage, listed from up to bottom are:

- thickness of element;

- porosity or content of the free water in concrete;

- paste volume;

- binder fineness;

- temperature and relative humidity

Low water-cement ratio and small permeability of the high strength concrete have important role with drying shrinkage of concrete. If the water-cement ratio is so low that almost all water is used in the cement hydration process and relative humidity within the concrete falls below $80 \%$ then there is practically no humid exchange between concrete and typical external environment. Also small permeability of high strength concrete is a reason that concrete drying is extremely low if there is any drying at all. Therefore, drying shrinkage with high strength concretes is significantly lower than with ordinary strength concretes.

The ratio of autogenous shrinkage and drying shrinkage in total concrete shrinkage namely ordinary concrete and high strength concrete are presented on diagrams (figure 6. and 7.) [13].

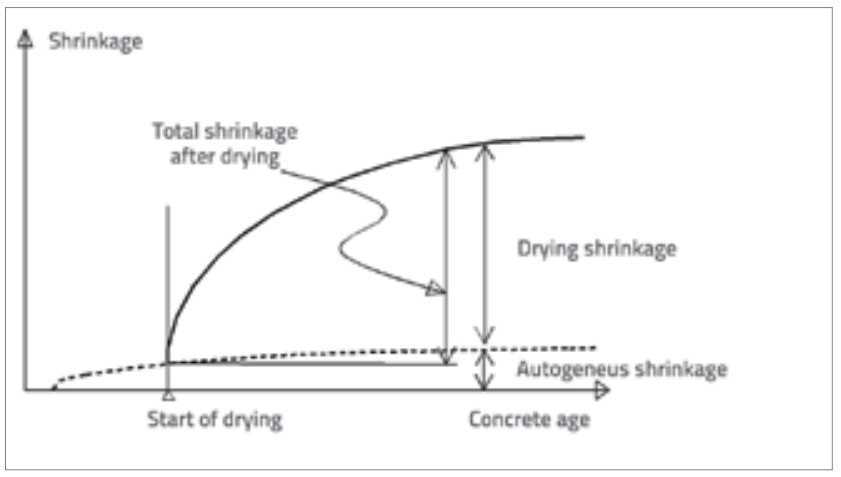

Figure 6. Shrinkage in ordinary concrete [13]

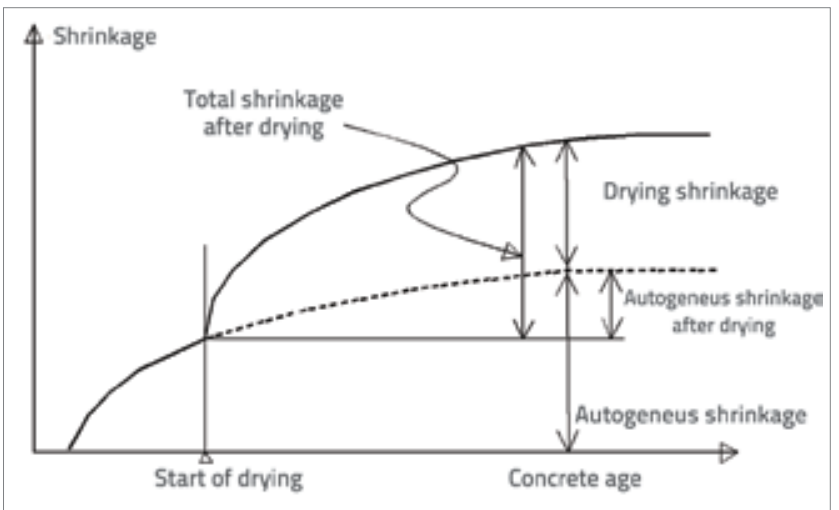

Figure 7. Shrinkage in high-strength concrete [13] 
Experimental results, which were published by Le Roy and Larrard [9] showed that with the decrease of water-cement ratio from 0,41 to 0,33 drying shrinkage decreases to $54 \%$. At SCC, also was observed an increase of drying shrinkage with increasing $w / c$ ratio [12]. Presence of micro silica in high strength concretes significantly decreases porosity of hydration cement paste especially in the narrow osculation area between cement paste and aggregate. It is more difficult to transfer water from the fine pores, and dense cement paste and qualitative narrow osculation area between aggregate and cement stone in high strength concrete with micro silica offer bigger resistance to the shrinkage.

This means that drying shrinkage of concrete decreases with adding micro silica. Sicard and Pons [14] claim we can decrease drying shrinkage of concrete by $50 \%$ if concrete mixture contains micro silica. Le Roy and De Larrard research [9] show that drying shrinkage with concrete where it was added $8 \%$ of micro silica considering cement mass, decreases by approximately $25 \%$.

Experiment conducted by the author [6], it was concluded that drying shrinkage is for about $27 \%$ less in high-strength concrete compared to ordinary concrete. Testing was carried out, as in the case of autogenous shrinkage, on prisms dimension $10 / 10 / 40 \mathrm{~cm}$, made of ordinary concrete with $\mathrm{w} / \mathrm{c}=0,58$ and high-strength concrete with $\mathrm{w} /$ $c=0,36$. Mean value of ordinary concrete drying shrinkage amounted $535 \times 10^{-6}$, and high strength concrete $419 \times 10^{-6}$ (Figure 8.).

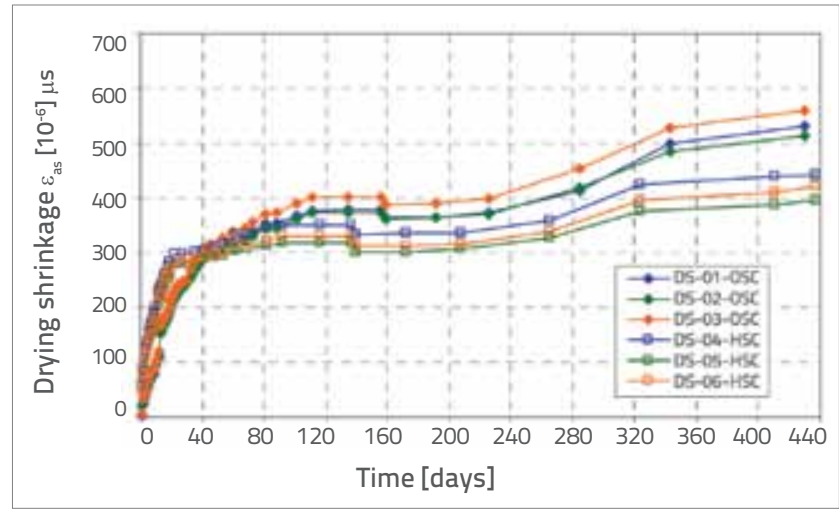

Figure 8. Drying shrinkage of ordinary strength concrete (OSC) and high-strength concrete (HSC)

\subsection{Thermal (temperature) shrinkage}

Temperature concrete strains occur in the early age (in the first days) due to temperature change caused by hydration process. During the chemical reaction of cement and water, concrete releases heat what causes concrete expansion and as process advances it occurs a mixture cooling, resulting in shrinkage deformation. How big the actual concrete temperature change will be depends on environment conditions and on the concrete composition. Selection of cement with certain characteristics should be emphasized. In construction designing, we usually look for early concrete strength or low hydration heat or improved resistance to chemically aggressive environment. Lower temperature of fresh concrete mixture results in slower increase of temperature and more uniform cooling i.e. more uniform dissipation of heat into the environment. That is way in the case of concreting in extremely hot climate we need to cool the fresh concrete mixture. However, more than very mineralogical composition, temperature at which the process of hydration occurs influences the speed of hydration release what has bigger effect on this type of shrinkage than on total hydration heat. Depending from the share and the type of cement, thermal (temperature) shrinkage can reach values from 400 to 500 $\times 10^{-6}$ within the concrete element, where the thickness of that element increases over a certain value. If the thickness of the concrete element is smaller than $30 \mathrm{~cm}$ (or $20 \mathrm{~cm}$ if only one side is exposed to cooling), thermal effects are equal to zero or they are very small. When thickness is bigger than $50 \mathrm{~cm}$ from the nearest surface exposed to cooling, concrete temperature will rise from 30 to $50^{\circ} \mathrm{C}$ (even to $55^{\circ} \mathrm{C}$ in a case of big contribution of high strength cements). In that case cracking of concrete in the direction of cooling is unavoidable. Dynamic of this shrinkage is simple: it starts with the end of binding process (maximal temperature is reached between 20 and $40 \mathrm{~h}$ ), and duration of cooling is proportional to thickness square.

\subsection{Carbonation shrinkage}

Carbonation shrinkage occurs in hardened concrete. $\mathrm{CO}_{2}$ (carbon dioxide) from the environment on cement stone causes chemical reactions. With water carbon dioxide makes carbon acid, which reacts with $\mathrm{C}_{a}(\mathrm{OH})_{2}$ (calcium hydra dioxide) in cement stone by making $\mathrm{C}_{\mathrm{a}} \mathrm{CO}_{3}$ (calcium carbonate) where other compounds of cement stone also degrade. Water releases during this reaction. There is $0,03 \%$ of carbon dioxide in non-polluted atmosphere. However, in cities and on highways there is 0,3\% of carbon dioxide. The speed of cement stone corrosion progress depends on pore structure but more of their water fill [5] (Figure 9.). Progress of carbon dioxide will be the slowest if pores are filled with water but if there is no water in pores, there is no carbonic acid i.e. there is no reaction in the lime crystals. Therefore, optimal conditions for carbonation of cement stone are partly in the moist concrete.

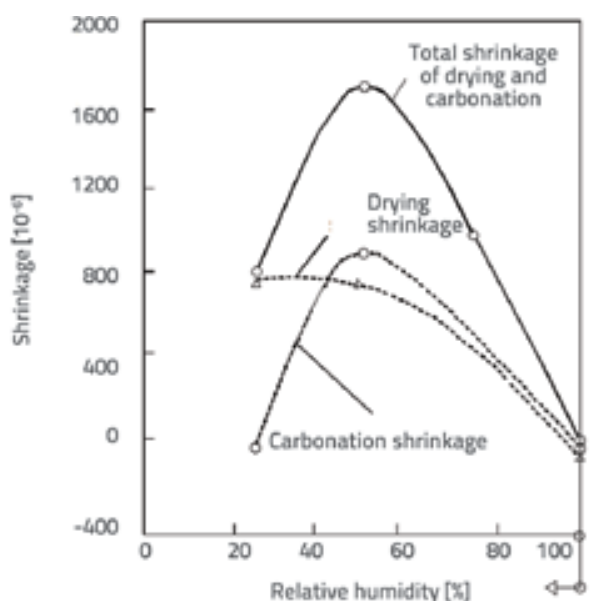

Figure 9. Draying shrinkage and carbonation shrinkage of cement mortar in different relevant humidities [5] 
Except for shrinkage, result of cement stone carbonation from the ordinary Portland cement can be increase of strength because the lime crystals are replaced with stronger calcium carbonate, which fills the structure, so water that is released can intensify the process of hydration. During carbonation, the concrete strength is increasing, therefore, the thin surface layers of the concrete crust becomes harder. Concrete made of cement with the addition of slag has on surface dusty layer due to carbonization.

\section{Concluding discussion about the shrinkage strain}

The paper explains the basic types of shrinkage: carbonation shrinkage, plastic shrinkage, temperature shrinkage, chemical shrinkage, autogenous shrinkage, and drying shrinkage. This division was obtained after reviewing and analyzing a large number of relevant literature.

Therefore, total shrinkage should be taken as the sum of each individual volume change due to carbonation, thermal change, drying and autogenous shrinkage. The cause of all types of shrinkage (except carbonation shrinkage) is a loss i.e. usage of water in concrete. Water can exit from the concrete into environment or it can be used during cement hydration. Carbonation shrinkage occurs in the hardened concrete and it is particularly visible in construction on highways and big cities (carbon dioxide is present up to 0,3\%).

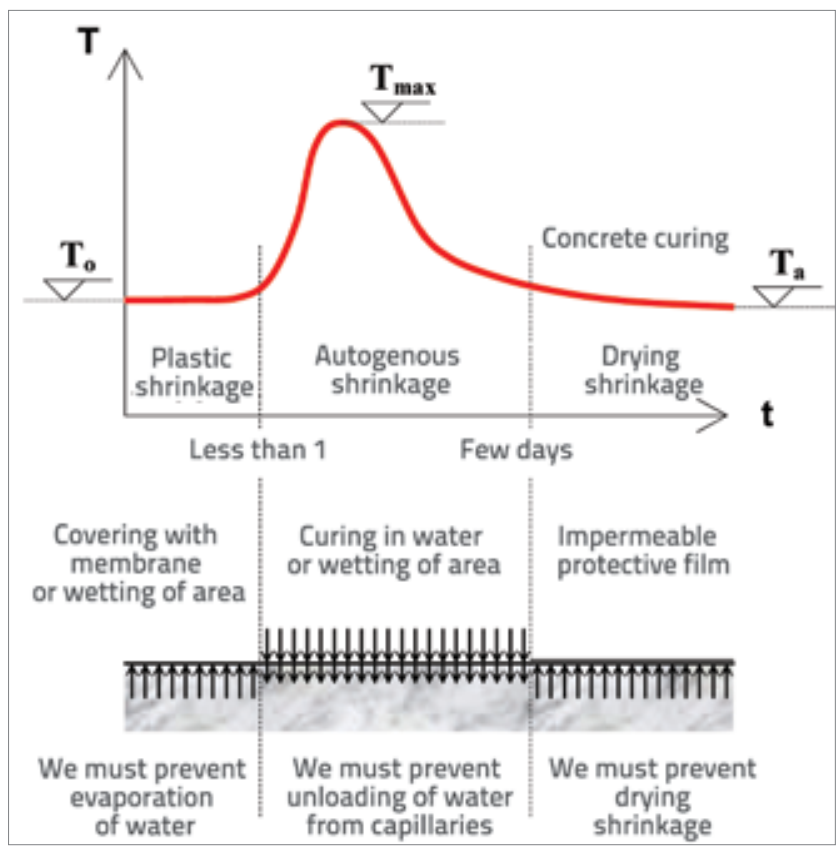

Figure 10. The course of temperature changes in concrete constructive element and schematic review of necessary flow of element curing [7]

Having in mind that the thermal expansion is reversible reaction over time, it is not included in definitive value of total shrinkage. This type of shrinkage has bigger influence on massive constructive elements (for example, dams, basic foundations), when these elements are exposed to conditions of prevented ultimate strains i.e. when one side is thermally isolated (for example, pavements) as well as when concreting in extremely hot climate conditions. Influence of thermal (temperature) shrinkage interferes with their autogenous shrinkage with these types of constructions, which is clearly visible in figure 10. Figure represents diagram of temperature and time dependence in relation to three basic types of shrinkage, where $T_{0}$ presents beginning temperature of fresh concrete, $T_{a}$ environment temperature and $T_{\max }$ maximal temperature during the process of hydration [7].

We are noticing from the moment of concrete casting that it is important to prevent evaporation of water from concrete i.e. to prevent plastic shrinkage on the surface of the concrete which is in the process of hardening. We are achieving this by wetting of the concrete surface or by covering of membrane. Plastic shrinkage the largest is in comparison with other types of shrinkage, but it is developing very fast in the first several hours and as such mainly it is not registered. Typically, it is not significant compared to stress conditions of constructions because it is happening in the fluid mass of the fresh concrete. Furthermore, when the increase of temperature in concrete reaches the highest level due to process of hydration of cement, the highest autogenous shrinkage is present in element. In that period, we need to cure in water or to wet the surface in order to prevent of unloading of water from capillaries. After several days when we finish with water curing, we cover construction with impermeable film, so that we can prevent drying shrinkage.

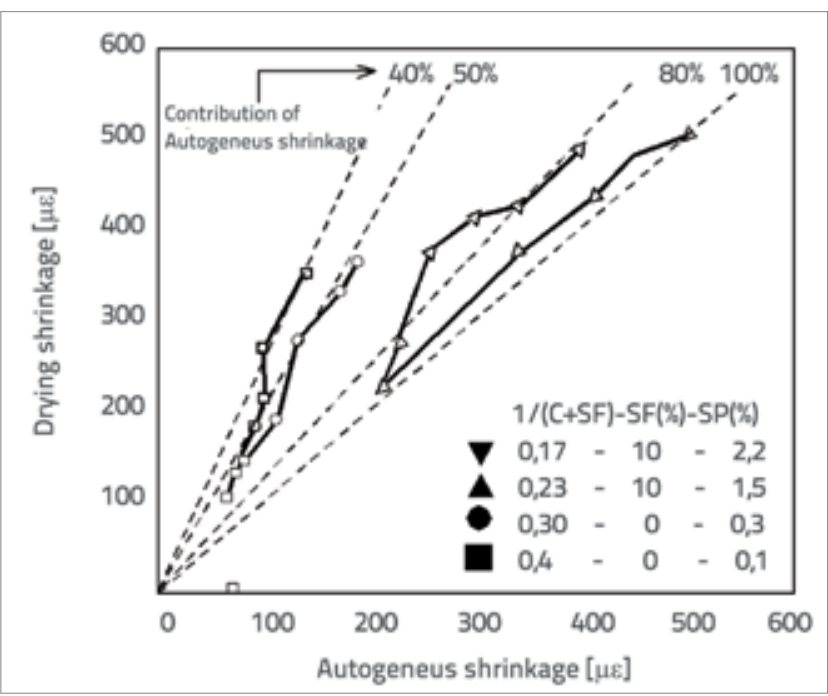

Figure 11. Drying shrinkage and autogenous shrinkage relation at low water-cement ratios [2]

For high-strength concrete as already stated, where the phenomenon of self-desiccation is expressed i.e. 
autogenous shrinkage is very large, curing in water or wetting the surface will not prevent draining water in the capillaries, because the water cannot penetrate into the concrete of low permeability [15]. The solution to this problem is internal curing. It is based on the application of pre-soaked lightweight aggregate or other porous materials, which conserves water inside the mixture, preventing the reduction of relative humidity [16].

Thus, the two basic components of the total shrinkage are autogenous shrinkage and drying shrinkage. Water-cement ratio of 0,4 autogenous shrinkage amounts to $40 \%$ of total shrinkage magnitude, while at water-cement ratio of 0,23 autogenous shrinkage amounts to $80 \%$. It is obvious that autogenous shrinkage cannot be avoided, but in the most of cases we assume that it is so low that we can consider it as insignificant, particularly for ordinary strength concrete with $w / c$ ratio greater than 0,45 . While with high-strength concretes that have very low water-cement ratio $(w / c<0,40)$ autogenous shrinkage represents an important part of the total shrinkage [2]. Drying shrinkage of concrete at highstrength concrete is significantly lower than with ordinary strength concrete due to low water-cement ratio and low permeability. Drying shrinkage depends on the thickness of the element, binders grinding fineness, as well as environmental conditions (temperature and humidity).

Today, the precise ratio of these two types of shrinkage, autogenous shrinkage and drying shrinkage, within the total shrinkage value is unknown in most of the cases, especially in the early age and with high strength concretes as well with high-performance concrete.

\section{REFERENCES}

[1] Comité Euro-International du Béton: SERVICEBILITY MODELS Behavior and modelling in servicebility limit states including repeated and sustained loads, CEB Bulletin d Information $N^{\circ}$ 235, Progres report, pp. 57-68, 1997

[2] Holt, E.: Early age autogenous shrinkage of concrete, VTT Building and Transport, Technical research centre of Finland, ESPOO, pp. 22-47, 2001.

[3] Tazawa, E.: Autogenous Shrinkage of Concrete, Proceedings of the International Workshop organized by JCl (Japan Concrete Institute), E\&FN Spon, London, Hiroshima, pp. 411, 1998.

[4] Muravljov, M.: Građevinski materijali, Građevinska knjiga, Beograd, 2007.

[5] Ukrainczyk, V.: Beton - Struktura, Svojstva, Tehnologija, udžbenik Sveučilišta u Zagrebu, Zagreb, pp. 147-154, 259-264, 1994.

[6] Šahinagić-Isović, M.: Influence of steel fiber reinforcement to the behavior of reinforced concrete beams, University "St. Cyril and Methodius" of Skopje, Civil Engineering faculty, Doctoral thesis, pp. 38-59, 2010

[7] Saje, D.: Krčenje betonov visoke trdnosti v prvih dneh po vgraditivi, 12. slovenski kolokvij o betonih - Nosivosti pri gradnji tlakov, Ljubljana, 2005.

[8] Van Breugel, M.: Additional Remarks on the Risk of Cracking in Hardening Concrete, Proceedings of Rilem International Conference on Concrete at Early Ages, Paris, Vol. 2, (1982.), pp. 103-108.

[9] Le Roy, R., De Larrard, F.: Creep and shrinkage of highperformance concrete. Proceedings of the 5th International Symposium on Creep and Shrinkage of Concrete, Barcelona, Spain, 6-9 September 1993, pp. 499-504.
[10] Aguado, A., Gettu, R.: Creep and Shrinkage of High-Performance Concrete, Proceedings of the 5th International Symposium on Creep and Shrinkage of Concrete, Barcelona, Spain, 6-9 September 1993, pp. 481-492.

[11] Koh, K., Ryu, G., Kang, S., Park, J., Kim, S.: Shrinkage Properties of Ultra-High Performance Concrete (UHPC), Advanced Science Letters, Volume 4, Number 3, (2011.), pp. 948-952.

[12] Aslani F., Nejadi S.: Shrinkage behavior of self-compacting concrete, Journal of Zhejiang University-SCIENCE A (Applied Physics \& Engineering), Vol.13(6), (2012.), pp. 407-419.

[13] Sakata, K., Shimomura, T.: Recent progress in research on and code evaluation of concrete creep and shrinkage in Japan, Journal of Advanced Concrete Technology 2, (2004.) 2, pp. 133-140.

[14] Sicard, V., Pons, G.: High-Performance Concrete: Some Phenomena in Relation to Desiccation, Materials and Structures, Vol.25, (1992.), pp. 591-597.

[15] Zhutovsky, S., Kovler, K., Bentur, A.: Revisiting the protected paste volume concept for internal curing of high-strength concretes, Cement and Concrete Research, Vol.41, (2011.), pp. 981-986.

[16] Zhutovsky, S., Kovler, K., Bentur, A.: Influence of cement paste matrix properties on the autogenous curing of highperformance concrete, Cement \& Concrete Composites, Vol.26, (2006.), pp. 499-507. 